UCRL-JC-129103

PREPRINT

\title{
Thin Film Synthesis of Novel Electrode Materials for Solid-Oxide Fuel Cells
}

\author{
Alan F. Jankowski \\ Jeffrey D. Morse
}

This paper was prepared for submittal to the

The Materials Research Society 1997 Fall Meeting

December 1, 1997

Boston, MA

December 1997

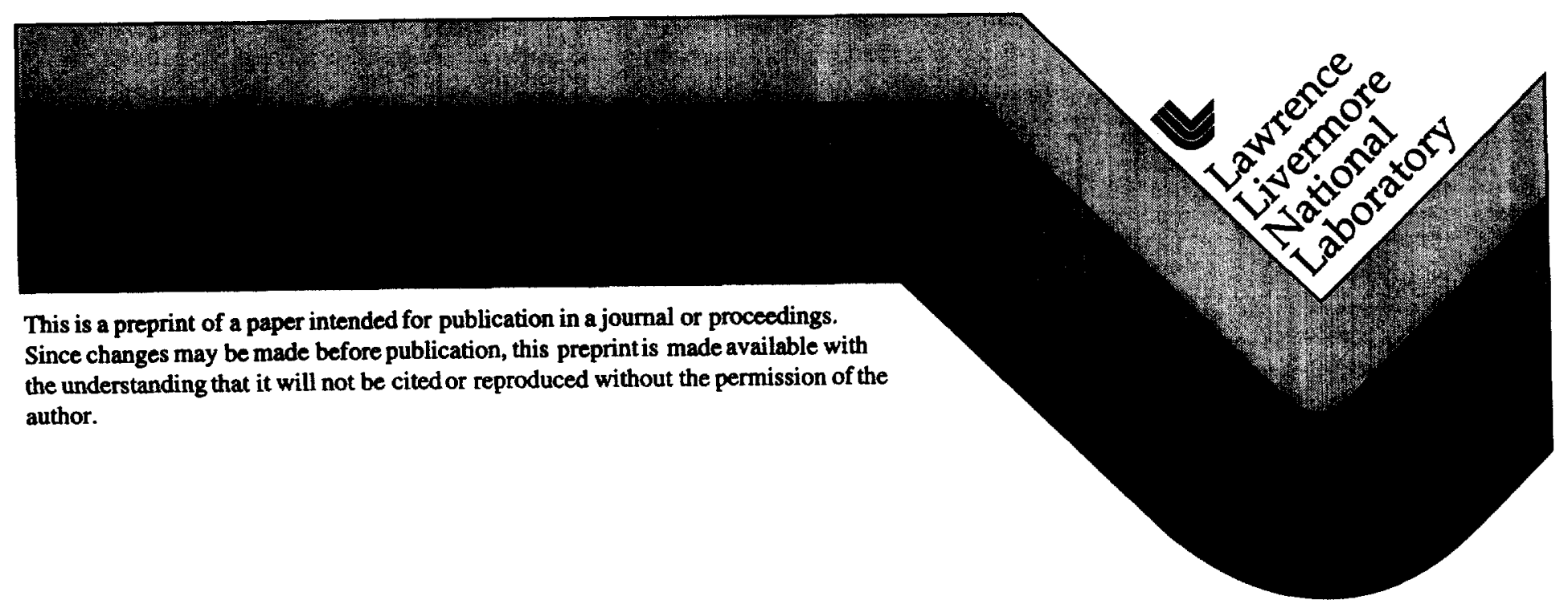




\section{DISCLAIMER}

This document was prepared as an account of work sponsored by an agency of the United States Government. Neither the United States Government nor the University of California nor any of their employees, makes any warranty, express or implied, or assumes any legal liability or responsibility for the accuracy, completeness, or usefulness of any information, apparatus, product, or process disclosed, or represents that its use would not infringe privately owned rights. Reference herein to any specific commencial product, process, or service by trade name, trademark, manufacturer, or otherwise, does not necessarily constitute or imply its endorsement, recommendation, or favoring by the United States Government or the University of California. The views and opinions of authors expressed herein do not necessarily state or reflect those of the United States Government or the University of California, and shall not be used for advertising or product endorsement purposes. 


\section{THIN FILM SYNTHESIS OF NOVEL ELECTRODE MATERIALS FOR SOLID-OXIDE FUEL CELLS}

Alan F. Jankowski and Jeffrey D. Morse

University of California - Lawrence Livermore National Laboratory

P.O. Box 808, Livermore, CA 94550

\section{ABSTRACT}

Electrode materials for solid-oxide fuel cells are developed using sputter deposition. A thin film anode is formed by co-deposition of nickel and yttria-stabilized zirconia. This approach is suitable for composition grading and the provision of a mixed-conducting interfacial layer to the electrolyte layer. Similarly, synthesis of a thin film cathode proceeds by co-deposition of silver and yttria-stabilized zirconia. The sputter deposition of a thin film solid-oxide fuel cell is next demonstrated. The thin film fuel cell microstructure is examined using scanning electron microscopy whereas the cell perfomance is characterized through current-voltage measurement and corresponding impedance spectroscopy.

\section{INTRODUCTION}

A solid-oxide fuel cell (SOFC) device consists of manifolded stacks of cells which combine a fuel and oxidant at elevated temperatures to generate electric current. The basis of each fuel cell is an anode and cathode separated by an electrolyte layer. SOFCs provide an efficient and enviromentally clean method of energy conversion. SOFCs are routinely made using bulk ceramic powder processing. 1 A traditional synthesis approach uses a cermet electrode on which an electrolyte is layered, for example by tape casting, and the cell completed through lamination with the counterpart electrode. SOFCs are operated at temperatures that often exceed $900^{\circ} \mathrm{C}$.

The common approach to incorporate thin film technologies in SOFCs is based on coating the cermet electrodes with an electrolyte layer. To decrease the thickness below that obtainable using tape calendaring, thin ceramic films can be deposited by a variety of techniques including variations of sol-gel and colloidal deposition. ${ }^{2}$ In addition, thin electrolyte layers can be dc magnetron sputtered from metal alloy targets to optimize ion conductivity and rf magnetron sputtered from oxide targets to form continuous coatings on porous substrates. ${ }^{3-5} \mathrm{~A}$ thin electrolyte reduces the path for oxygen ion diffusion. A decrease in the electrolyte thickness from $\sim 100 \mu \mathrm{m}$ to $<10 \mu \mathrm{m}$ can potentially lower the fuel cell operating temperature by several hundred degrees centigrade. 6 Although a thin electrolyte layer can be deposited onto an electrode, a bonding procedure is still required to attach the counterpart electrode and form the unit cell of the anode-electrolyte-cathode trilayer. This process always leads to polarization losses at the electrode-electrolyte interface(s). To address this problem, interfacial layers can be added at both the anode and cathode sides of the electrolyte to reduce interfacial reaction resistances. ${ }^{7,8}$ For example, yttria-stabilized $\mathrm{Bi}_{2} \mathrm{O}_{3}$ is added at the cathode-side and yttria-doped $\mathrm{CeO}_{2}$ is added at the anode-side of the yttria-stabilized zirconia (YSZ) electrolyte layer.

Thin film processing can be used to produce alternative cermet electrodes.9,10 Anodes for a YSZ electrolyte can be synthesized as thin wafers. For example, the anode wafers can be sintered compacts of $\mathrm{Ni}$-coated zirconia powder. Metal coating the zirconia powder uniformally distributes the conducting element of the electrode. Sufficient electrical conduction is provided while reducing the metal content to $<10$ volume percent ensuring a near match in coefficient of thermal expansion match to the electrolyte. In comparison, bulk cermet processing involves sintering a powder composite that often contains $>30$ volume percent metal. The high metal content is needed to yield sufficient conductivity at elevated temperature but often leads to a delamination failure when subjected to routine thermal-cycling.

Chemical and physical vapor deposition methods are shown advantageous to produce either the electrolyte layer or the electrodes. A clear advantage exists to explore additional methods to form the anode-electrolyte-cathode trilayer through an integrated synthesis procedure. In 
addition to the use of vacuum deposition to form electrolyte thin films, we investigate the use of sputter deposition to form both electrodes as thin films and to provide a composition graded electrode-electrolyte interface for improved kinetics. We will examine electrode materials for a SOFC based on a YSZ electrolyte that is compatible with low temperature $\left(<700^{\circ} \mathrm{C}\right)$ operation. Specifically, nickel (Ni)-YSZ is selected for the anode and silver (Ag)-YSZ for the cathode.

\section{EXPERIMENTALS}

The use of thin film deposition enables the fuel cell unit to be synthesized in a continuous process. A sequential deposition starting with the anode and concluding with the cathode bridges the difficulties of joining electrolyte-coated electrodes (e.g. anodes) to counterpart electrodes (e.g. cathodes). The electrodes are formed as metal and ceramic composites by the co-sputter deposition of targets operated in the dc- and rf-modes, respectively. The ceramic material chosen for the electrode matrix is the same as that used for the vapor deposition of the electrolyte layer. Synthesis of a dense, thin electrolyte layer is established by the rf-sputter deposition of a $\left(\mathrm{Y}_{2} \mathrm{O}_{3}\right)_{5.6}\left(\mathrm{ZrO}_{2}\right)_{94.4}$ target.5 $\mathrm{A}$ defect-free electrolyte layer of cubic YSZ is confirmed through transmission electron microscopy (TEM) plan-view bright-field imaging and selected-area electron diffraction.

To synthesize a thin film fuel cell with an exposed free-standing region suitable for subsequent testing, a brief review of the substrate platform preparation is necessary. A thin layer of silicon nitride is first applied to the substrate surface using a low pressure chemical vapor deposition process. A $0.22 \mu \mathrm{m}$ thick film is formed at a $800^{\circ} \mathrm{C}$ temperature using a $112 \mathrm{~cm}^{3} \mathrm{~m}^{-1}$ flow of dichlorosilane and a $30 \mathrm{~cm}^{3} \mathrm{~m}^{-1}$ flow of $\mathrm{NH}_{3}$ at a $33 \mathrm{~Pa}$ pressure. The backside of the wafer is patterned by standard photolithographic techniques and etched to reveal windowed regions of silicon nitride with areas that range from 0.14 to $16 \mathrm{~mm}^{2}$ in size. The substrate is etched at a rate of $1 \mu \mathrm{m} \mathrm{m}^{-1}$ as using $44 \% \mathrm{KOH}$ at $85^{\circ} \mathrm{C}$. An etch rate of $0.42 \mu \mathrm{m} \mathrm{m}^{-1}$ is achieved during nitride removal using $500 \mathrm{~W}$ of power with a $2.7 \mathrm{~Pa}$ pressure at a $40 \mathrm{~cm}^{3} \mathrm{~m}^{-1}$ flow of $\mathrm{CHF}_{3}$ and a $80 \mathrm{~cm}^{3} \mathrm{~m}^{-1}$ flow of $\mathrm{CF}_{4}$.

The sequence of deposition process steps to synthesize the fuel cell unit is reviewed as follows. The deposition chamber is evacuated to a base pressure of $5.3 \times 10^{-6} \mathrm{~Pa}$. The substrate is positioned $10 \mathrm{~cm}$ from an array of three planar magnetron sources. The $5 \mathrm{~cm}$ diameter YSZ source is positioned between two $3 \mathrm{~cm}$ diameter sources that are positioned $60^{\circ}$ apart. One $3 \mathrm{~cm}$ source has a Ag target and the other a $\mathrm{Ni}$ target. To minimize residual stress effects that arise when depositing YSZ using high sputter-gas pressures at elevated substrate temperatures, a low $\left(<50^{\circ} \mathrm{C}\right)$ temperature deposition is followed by an air anneal at the cell operating temperature for several hours. A $10 \mathrm{~Pa}$ sputter gas pressure at a constant flow of $30 \mathrm{~cm}^{3} \mathrm{~m}^{-1}$ is used to operate the magnetron sources. Each step of the following process adds an increment of thickness ( $\Delta t)$ to the total thickness $\left(t_{f}\right)$ at that stage of the deposition. (Step-1) The deposition begins by sputtering the Ni target at $4.2 \mathrm{Wcm}^{-2}$ power yielding a $9.3 \mathrm{~nm} \mathrm{~m}^{-1}$ rate to give a $\Delta \mathrm{t}$ of $0.3 \mu \mathrm{m}\left(\mathrm{t}_{\mathrm{f}}=0.3 \mu \mathrm{m}\right)$. (Step-2) The deposition continues as the YSZ target is sputtered at $38.2 \mathrm{Wcm}^{-2}$ power yielding a $10.6 \mathrm{~nm} \mathrm{~m}^{-1}$ rate. The Ni and YSZ are co-deposited to a $\Delta t$ of $0.5 \mu \mathrm{m}\left(\mathrm{t}_{\mathrm{f}}=0.8 \mu \mathrm{m}\right)$. (Step-3) The deposition continues as the YSZ target is sputtered alone to give a $\Delta t$ of $0.7 \mu \mathrm{m}\left(\mathrm{t}_{\mathrm{f}}=1.5 \mu \mathrm{m}\right)$. (Step-4) The deposition continues as the Ag target is sputtered at $4.2 \mathrm{Wcm}^{-2}$ power yielding a $33.3 \mathrm{~nm} \mathrm{~m}^{-1}$ rate. The YSZ and Ag are co-deposited to a $\Delta t$ of $1.2 \mu \mathrm{m}\left(\mathrm{t}_{\mathrm{f}}=2.7 \mu \mathrm{m}\right)$. (Step-5) The deposition concludes as the Ag target is sputtered alone to a $\Delta \mathrm{t}$ of $0.8 \mu \mathrm{m}\left(\mathrm{t}_{\mathrm{f}}=3.5 \mu \mathrm{m}\right)$.

\section{RESULTS \& DISCUSSION}

A thin-film solid-oxide fuel cell (TFSOFC) consisting of a Ni-(YSZ) anode, a YSZelectrolyte, and a Ag-(YSZ) cathode (Fig. 1) is formed through the continuous deposition process. Scanning electron microscopy indicates that the electrolyte and electrode layers appear continuous both in-plane and through the growth direction. As mentioned, interfacial layer additions or a composition-graded electrolyte-electrode interface (as is featured in this sample) can be added to improve the fuel cell performance by enhancing catalytic activity. 


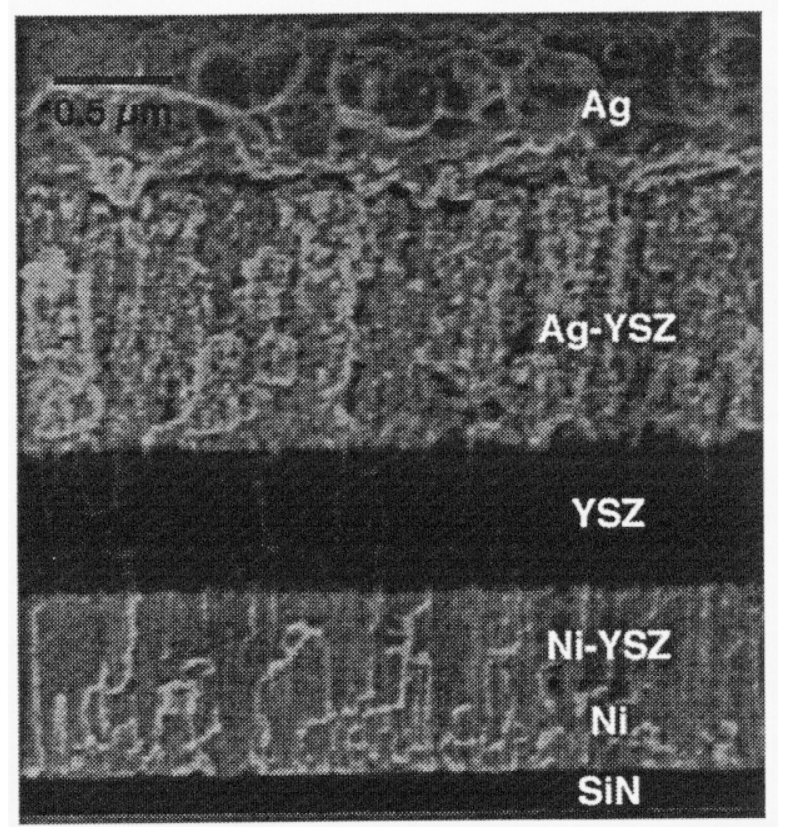

Fig. 1. A thin film solid-oxide fuel cell as deposited by planar magnetron sputtering is viewed in cross-section.

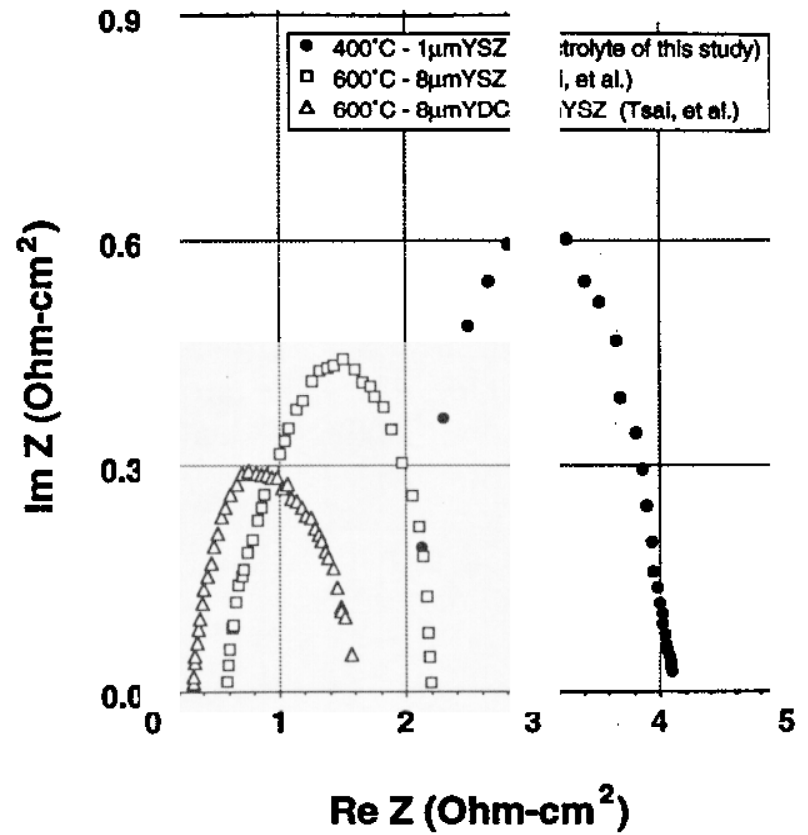

Fig. 2. Impedance spectra of the thin film solid-oxide fuel cell indicate low electrolyteelectrode polarization losses.

The current-voltage (i-V) output of a Ni-(YSZ)/YSZ/Ag-(YSZ) fuel cell is measured as the current across the solid electrolyte is controlled by a galvanostat. After the fuel cell is heated to $400^{\circ} \mathrm{C}$ in dry $\mathrm{N}_{2}$, air is supplied as the oxidant to the cathode and a humidified $6 \%$ hydrogen (Arbalance) fuel mixture is supplied to the anode. The measurement of power generation requires that the active area of the thin film cell be free-standing. After the sputter deposition process, the thin support windows of nitride are removed by reactive-ion etching to expose the fuel cell anode over a well-defined area. The $\mathrm{i}-\mathrm{V}$ output measurements are conducted over square regions that range from 2 to $9 \mathrm{~mm}^{2}$ in size. An open circuit voltage (OCV) of $-1.0 \mathrm{~V}$ is estimated in preliminary testing along with a short-circuit current of $\sim 240 \mathrm{mAcm}{ }^{-2}$ that corresponds to a resistance of $\sim 4 \Omega \mathrm{cm}^{2}$. The OCV is less than the $1.1 \mathrm{~V}$ expected but is similar to that obtained for other SOFCs of Ni-YSZ-Ag that are formed using a sputtering process for deposition of the electrolyte layer. ${ }^{8}$ The cell exhibits somewhat of a non-linear $\mathrm{i}-\mathrm{V}$ response. The non-ohmic behavior is seen as the resistance decreases with increasing current. The preliminary testing at $400^{\circ} \mathrm{C}$ generates a maximum power density of $39 \mathrm{mWcm}^{-2}$ for the TFSOFC. This cell output is comparable with the maximum power density generated for SOFCs composed of a Ni-YSZ anode and a $\mathrm{La}_{.85} \mathrm{Sr}_{.15} \mathrm{MnO}_{3}$-YSZ cathode.11 A SOFC with an $8 \mu \mathrm{m}$ thick yttria-doped ceria (YDC) - $1 \mu \mathrm{m}$ thick YSZ electrolyte bilayer yields $43 \mathrm{mWcm}^{-2}$ at $500^{\circ} \mathrm{C}$ and $155 \mathrm{mWcm}^{-2}$ at $600^{\circ} \mathrm{C}$ as tested using a $10 \%$ hydrogen fuel mixture. The power generated at $600^{\circ} \mathrm{C}$ decreases to $110 \mathrm{mWcm}^{-2}$ for a SOFC with a single $8 \mu \mathrm{m}$ thick YSZ electrolyte layer.

The electrochemical impedance spectra (Fig. 2) provide a measure of the polarization losses that are found within the cell. A separate $\mathrm{Ni}$-(YSZ)/YSZ/Ag-(YSZ) fuel cell is measured after it is heated to $400^{\circ} \mathrm{C}$. Air is supplied to the cathode and the humidified $6 \%$ hydrogen (Ar-balance) fuel mixture to the anode. The plot of the real versus imaginary components of the complex spectra forms a semicircular arc for the TFSOFC of Ni-(YSZ)/YSZ/Ag-(YSZ). Results at $600^{\circ} \mathrm{C}$ are also shown for the SOFCs referenced in the $\mathrm{i}-\mathrm{V}$ comparison. ${ }^{11}$ The real-axis intercepts give the total ohmic losses for the fuel cells. The high frequency intercept indicates that the electrolyte area-specific resistance for the TFSOFC at $400^{\circ} \mathrm{C}$ is only $2 \Omega \mathrm{cm}^{2}$. This resistance value compares favorably with the output of the SOFC with the $8 \mu \mathrm{mYDC}-1 \mu \mathrm{mYSZ}$ electrolyte bilayer operated at a higher temperature of $500^{\circ} \mathrm{C} .11$ An equivalent resistance value of $2 \Omega \mathrm{cm}^{2}$ is also reported at $500^{\circ} \mathrm{C}$ for measurements of a $9 \mu \mathrm{m}$ thick YSZ electrolyte layer. ${ }^{12}$ In all, the fuel cell $\mathrm{i}-\mathrm{V}$ output at low temperature proves fairly consistent with the impedance spectra results. 


\section{SUMMARY}

Thin film and multilayer deposition technology provides a means to synthesize thin-film solid-oxide fuel cells (TFSOFCs) that can potentially yield greater specific power than found in any other available fuel cell configuration. Substrates were patterned and processed to reveal well-defined windowed regions. The anode is deposited first by sputtering $\mathrm{Ni}$ and co-depositing YSZ. The synthesis continues through the electrolyte layer with deposition of only YSZ, into the cathode via co-deposition with $\mathrm{Ag}$, and concluding with $\mathrm{Ag}$ alone. The substrate windows are removed by etching to expose a self-supporting anode-electrolyte-cathode trilayer that constitutes the TFSOFC. The current-voltage output from the cell is measured using a hydrogen fuel mixture and air as the oxidant. The TFSOFC yields an acceptable fuel cell performance but at a through thickness orders of magnitude less than that achievable using conventional processing. Our approach to SOFC synthesis is novel in several ways: (i) the electrodes are cosputter deposited thin films; (ii) a provision exists for the deposition of mixed conducting interfaces; (iii) the entire fuel cell is formed as a thin film through a continuous deposition process; and (iv) the TFSOFC is half the thickness of just the electrolyte layer as produced through state-of-the-art processing.

\section{ACKNOWLEDGMENTS}

We thank J. Hayes for his asssistance in sample fabrication, J. Ferreira for the scanning electron microscopy imaging and $\mathrm{Q}$. Pham for his assistance during initial impedance spectroscopy measurements. This work was performed under the auspices of the United States Department of Energy by Lawrence Livermore National Laboratory under contract \#W-7405-Eng-48.

\section{REFERENCES}

1. N. Minh, J. American Ceramic Society 76, 563 (1993).

2. S. deSouza, S. Visco and L. DeJonghe, Solid State Ionics 98, 57 (1997).

3. E. Thiele, L. Wang, T. Mason and S. Barnett, J. Vac. Sci. Technol. A 9, 3054 (1991).

4. A. Jankowski and J. Hayes, Surface and Coatings Technology 76-77, 126 (1995).

5. A. Jankowski and J. Hayes, J. Vac. Sci. Technol. A 13, 658 (1995).

6. S. Barnett, Energy 15, 1 (1990).

7. L. Wang and S. Barnett, J. Electrochemical Society 139, 2567 (1992); ibid., 139, L89 (1992).

8. L. Wang and S. Barnett, Solid State Ionics 61, 273 (1993).

9. A. Jankowski, Internat. J. Environmentally Conscious Design \& Manufacturing 5, 39 (1996).

10. A. Jankowski, in Ionic and Mixed Conducting Ceramics III, edited by T. Ramanarayanan (The Electrochemical Society Proceeding Series PV-24, Pennington, NJ, 1997) in press.

11. T. Tsai, E. Perry and S. Barnett, J. Electrochemical Society 144, L130 (1997).

12. A. Atkinson, in Proceedings of the Second European Solid-Oxide Fuel Cell Forum, edited by B. Thorstensen (The Electrochemical Society, Pennington, NJ, 1996) p. 707. 


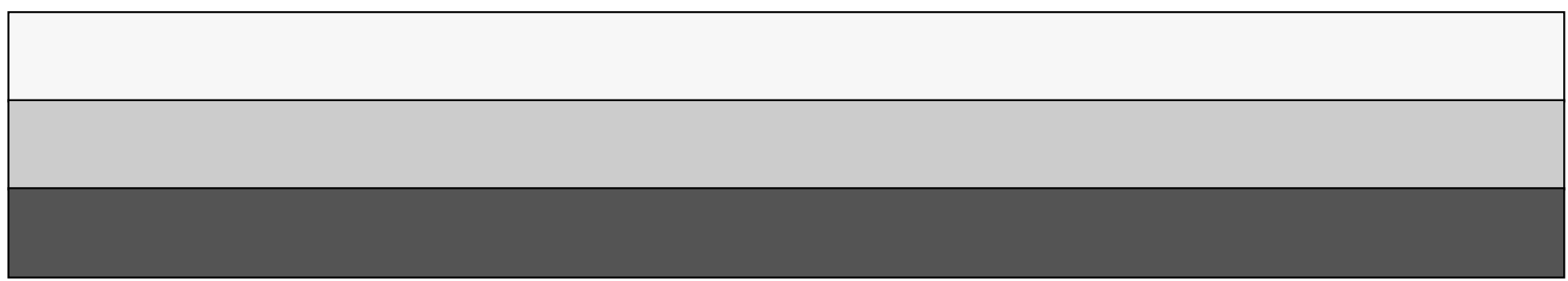

